\title{
PENINGKATAN PRESTASI BELAJAR IPS MELALUI MODEL PEMBELAJARAN KOOPERATIF TIPE NHT PADA SISWA KELAS V
}

\author{
Lina Dwi Komala Sudarnoto, S.Pd.SD \\ SDN 2 Pandak Baturaden Banyumas \\ email: linadwi17621@gmail.com
}

\begin{abstract}
ABSTRAK
Penelitian Tindakan Kelas ini bertujuan untuk meningkatkan motivasi dan prestasi belajar siswa dengan menggunakan model pembelajaran Numbered Head Together (NHT) pada siswa kelas V SDN 2 Pandak Korwilcam Dindik Baturraden yang berjumlah 22 siswa. Penelitian Tindakan Kelas ini dilakukan dalam 2 siklus, dimana setiap Setiap siklus meliputi perencanaan, pelaksanaan tindakan, observasi,dan refleksi. Teknik pengumpulan data yang digunakan untuk mengukur kemampuan siswa dalam penguasaan materi pelajaran yang telah diberikan, pada setiap akhir siklus diadakan evaluasi dengan menggunakan tes tertulis yang terdiri dari 10 butir soal Isian dan 5 butir soal uraian, sedangkan untuk mengetahui seberapa besar motivasi siswa dalam pembelajaran IPS, siswa diminta mengisi angket pada setiap akhir siklsus. Hasil penelitian pada pembelajaran IPS dengan menggunakan model pembelajaran Numbered Head Together (NHT) dapat meningkatkan motivasi dan prestasi belajar siswa.diantaranya (1) hasil tes menunjukan peningkatan nilai rata-rata kelas ,(2) persentase siswa yang mencapai nilai KKM yang di tetapkan meningkat;(3)respons siswa terhdap pembelajaran IPS tentang Keragaman Suku Bangsa dan Budaya dengan Model NHT dalam kategori baik.
\end{abstract}

Kata Kunci : Motivasi dan Prestasi Belajar, Pembelajaran Numbered Head Together (NHT), Ilmu Pengetahuan Sosial

\section{PENDAHULUAN}

Mata pelajaran IPS adalah bidang studi yang mempelajari, menelaah, menganalisis gejala dan masalah sosial di masyarakat dengan meninjau dari berbagai aspek kehidupan atau satu perpaduan. Dilihat dari definisinya sudah sangat jelas bidang garapan IPS cukup luas karena meliputi gejala - gejala dan masalah kehidupan manusia di masyarakat.. Tekanan yang dipelajari IPS berkenaan dengan masyarakat bukan teori dan keilmuannya melainkan pada kenyataan kehidupan kemasyarakatan. 
Oleh karena itu menjadi Guru IPS yang baik, secara minimal harus memiliki dasar - dasar pembelajaran IPS karena membelajarkan IPS di Sekolah Dasar bukan berarti mengajarkan disiplin ilmu - ilmu sosial, melainkan membelajarkan konsep - konsep esensi ilmu social untuk membentuk peserta didik menjadi warga negara yang baik.

Pembelajaran IPS pada saat ini sering dikatakan sebagai pembelajaran yang membosankan karena hanya mendengarkan ceramah Guru saja dan sifatnya hafalan sehingga saat ulangan formotif jikalau siswa tidak banyak membaca dan menghafal nilainya rendah

Pembelajaran Numbered Head Together (NHT) adalah salah satu jenis pembelajaran kooperatif dari diskusi kelompok yang dirancang agak berbeda yaitu hanya satu siswa yang mewakili kelompoknya tanpa diberi tahu dulu sebelumnya siswa yang akan mewakili kelompoknya dengan tujuan untuk mempengaruhi pola interaksi siswa dan sebagai alternatif terhadap struktur kelas tradisional.

Tujuan penelitian yang dilakukan menggunakan model pembelajaran Numbered Head Together (NHT) untuk mengetahui apakah pembelajaran menggunakan model pembelajaran Numbered Head Together (NHT) dapat meningkatkan motivasi siswa kelas V SD Negeri 2 Pandak, Korwilcam Dindik Baturraden pada mata pelajaran IPS materi Keanekaragaman Suku Bangsa dan Budaya Indonesia. Penelitian ini juga untuk mengetahui apakah model pembelajaran Numbered Head Together (NHT) dapat meningkatkan prestasi belajar siswa kelas V SDN 2 Pandak, Korwilcam Dindik Baturraden. Motivasi siswa dan model pembelajaran Numbered Head Together (NHT) saling berkaitan, dengan model pembelajaran Numbered Head Together (NHT) siswa diajak guru untuk aktif menggali informasi pengetahuan yang sedang mereka pelajari melalui pembelajaran kelompok dengan diskusi dan presentasi ke depan kelas dengan sistem menunjukk spontan salah satu siswa untuk mewakili kelompoknya dalam presentasi.

Menurut Sagala (2010 : 100) motivasi dapat dipahami sebagai suatu variabel penyelang yang digunakan untuk menimbulkan faktor - faktor tertentu di dalam organisme, yang membangkitkan, mengelola, mempertahankan, dan 
menyalurkan tingkah laku menuju suatu sasaran. Siswa yang belajar harus diberi motivasi untuk belajar dengan harapan, bahwa belajar akan memperoleh hasil. Siswa harus memperhatikan informasi yang relevan, maka ia telah siap untuk menerima pelajaran. Sedangkan menurut Sardiman (2007 : 75) motivasi dapat juga dikatakan serangkaian usaha untuk menyediakan kondisi-kondisi tertentu, sehingga seorang mau dan ingin melakukan sesuatu, dan bila ia tidak suka, maka akan berusaha untuk meniadakan atau mengelakkan perasaan tidak suka itu. Jadi motivasi itu dapat dirangsang oleh faktor dari luar tetapi motivasi itu adalah tumbuh di dalam diri seseorang. Menurut Anitah, dkk ( 2008: 27 ) keberhasilan belajar sangat dipengaruhi oleh dua faktor yaitu faktor dari dalam diri siswa itu sendiri (internal) dan faktor dari luar siswa (eksternal).

Menurut Nurhadi, dkk (2003:65) pada dasarnya Numbered Head Together (NHT) merupakan varian dari diskusi kelompok metode struktural yang dirancang untuk mempengaruhi pola-pola interaksi siswa yang digunakan untuk meningkatkan penguasaan akademik. Pelaksanaanya seperti metode resitasi yang ditandai dengan pengajuan pertanyaan oleh guru kepada seluruh siswa dalam kelas dan para siswa memberikan jawaban setelah lebih dahulu mengangkat tangan dan ditunjuk oleh guru. Menurut Slavin (2009:255-256) Numbered Head Together pada dasarnya adalah sebuah uraian dari grup diskusi, pembelokannya yaitu pada hanya satu siswa yang mewakili kelompoknya tetapi sebelumnya tidak diberi tahu siswa yang akan menjadi wakil kelompok tersebut. Pembelokan tersebut memastikan keterlibatan total dari semua siswa. Metode Russ Frank ini adalah cara yang sangat baik untuk menambahkan rasa tanggung jawab individual kepada diskusi kelompok.

Hasil penelitian diharapkan dapat memberikan kontribusi baik untuk guruguru SD, mahasiswa, maupun yang membaca karya ilmiah ini. Untuk peneliti sendiri yang sekaligus sebagai guru kelas $\mathrm{V}$, penelitian ini dapat mengembangkan teori pembelajaran IPS Materi Keanekaragaman Suku Bangsa dan Budaya Indonesia melalui model pembelajaran Numbered Head Together (NHT) untuk meningkatkan motivasi dan prestasi belajar siswa. Bagi pembaca dapat memberikan masukan dan dapat dicontoh dalam pelaksanaan pembelajaran. 


\section{METODE PENELITIAN}

Berdasarkan pengamatan pembelajaran di kelas $\mathrm{V}$, diperoleh hasil sebagai berikut : 1) Guru mengajarkan materi keragaman suku bangsa dan budaya dengan cara konvensional menulis di papan tulis tanpa media pembelajaran: 2). Proses pembelajaran belum mendapatkan hasil sesuai KKM; 3) Siswa kurang tertarik karena materi terlalu abstrak.

Berdasarkan hasil tersebut, disusun rencana penelitian tindakan untuk memperbaiki materi keragaman suku bangsa dan budaya. Hasil penyusunan tersebut sebagi berikut: 1) tersusunnya jadwal pelaksanaan tindakan siklus 1 ; 2) tersusunnya Rencana Pelaksanaan Pembelajaran ( RPP ) tentang materi yang diajarkan dan digunakan dalam tindakan: 3) tersedianya media yang akan digunakan dalam pembelajaran suku bangsa dan budaya dengan menggunakan model pembelajaran Numbered Head Together (NHT). 4) Tersusunya Lembar Kegiatan Siswa ( LKS ) yang digunakan dalam pembelajaran; 5) Tersusunnya kisi - kisi soal tes setelah tindakan siklus dan lembar soal tes setelah tindakan siklus 1; 6) Tersusunnya angket respon siswa yang diberikan pada akhir siklus 1 ; 7) Tersusunnya lembar observasi yang digunakan untuk mengetahui secara langsung pelaksanaan pembelajaran materi suku bangsa dan budaya.

Untuk mengetahui kemampuan awal siswa dilakukan tes. Dalam penelitian ini bentuk tes yang digunakan adalah tes tertulis hal ini dilakukan karena dipandang dapat memberikan indikasi yang baik dalam mengukur sejauh mana pemahaman siswa terhadap materi pelajaran yang didaptkan.

\section{HASIL DAN PEMBAHASAN}

Penelitian yang telah dilaksanakan selama dua siklus pada siswa kelas V SDN 2 Pandak, Korwilcam Dindik Baturraden pada mata pelajaran IPS materi Keanekaragaman Suku Bangsa dan Budaya dengan menggunakan model pembelajaran Numbered Head Together (NHT). Hasil penelitian dijelaskan sebagai berikut: 
Tabel 1. Hasil Angket Motivasi Siswa Siklus I dan II

$\begin{array}{lll}\text { Siklus } & \text { I } & \text { II } \\ \text { Jumlah } & 259 & 536 \\ \text { Rata-rata } & 25,6 & 38,29 \\ \text { Persentase } & 42 & 87 \\ \text { Kriteria } & \text { Baik } & \text { Sangat Baik }\end{array}$

Pada tabel 1 hasil angket di atas, rata-rata motivasi siswa meningkat dari siklus I ke siklus II yaitu dari rata-rata 25,6 dengan kriteria motivasi siswa baik menjadi 38,29 dengan kriteria motivasi siswa sangat baik. Hal ini menunjukkan bahwa pada saat proses pembelajaran berlangsung, motivasi siswa dalam belajar IPS materi Keanekaragaman Suku bangsa dan Budaya meningkat. Hal ini karena siswa dalam pembelajaran selalu berusaha untuk aktif menambah pengetahuan, mengikuti semua kegiatan yang dilakukan sehingga motivasi siswa juga meningkat pada setiap siklusnya.

Aktivitas guru selama proses pembelajaran dari siklus I ke siklus II mengalami peningkatan. Hasil kinerja guru tersebut dapat dilihat pada tabel 2

Tabel 2 Nilai rata-rata aktivitas guru setiap siklus

\begin{tabular}{llll}
\hline Siklus & Nilai rata-rata & Persentase & Kriteria \\
\hline I & 2,5 & $61,4 \%$ & Baik \\
II & 3,7 & $92 \%$ & Sangat Baik \\
\hline
\end{tabular}

Aktivitas guru pada siklus I diperoleh nilai rata-rata sebesar 2,5 dan siklus II sebesar 3,7. Ini menunjukkan bahwa kinerja guru mengalami peningkatan dari baik menjadi sangat baik baik. Perolehan nilai rata-rata pada siklus I sebesar 2,5 $(61,4 \%)$ yang berarti kinerja guru baik dan pada siklus II diperoleh nilai rata-rata sebesar 3,7 (92\%) yang berarti kinerja guru menjadi sangat baik. Dari data tersebut, menunjukkan bahwa kinerja guru dari siklus I ke siklus II mengalami peningkatan dari baik menjadi sangat baik.

Hal ini dikarenakan pemahaman guru tentang model pembelajaran Numbered Head Together (NHT) meningkat di setiap pertemuannya dan adanya diskusi antara guru 
dengan peneliti dalam pelaksanaan pembelajaran tersebut. Aktifitas siswa selama proses pembelajaran dari siklus I ke siklus II mengalami peningkatan. Hasil Aktifitas siswa tersebut dapat dilihat pada tabel 3

Tabel 3. Pengamatan Hasil Aktivitas Siswa Siklus I dan II

\begin{tabular}{llll}
\hline Siklus & $\begin{array}{l}\text { Rata-rata } \\
\text { siklus }\end{array}$ & Persentase & Kriteria Aktivitas \\
\hline I & 23,7 & $54 \%$ & Cukup baik \\
II & 38,5 & $87 \%$ & Sangat Baik \\
\hline
\end{tabular}

Aktivitas siswa pada siklus I diperoleh nilai rata-rata sebesar 23,7 (54\%) yang berarti aktivitas siswa cukup baik dan pada siklus II diperoleh nilai rata-rata sebesar 38,5 (87\%) yang berarti aktivitas siswa sangat baik. Aktivitas siswa dari siklus I sampai siklus II kriterianya menunjukkan peningkatan dari baik menjadi sangat baik. Hal ini dikarenakan dari pertemuan ke pertemuan yang lain siswa mulai terbiasa dengan pembelajaran menggunakan model pembelajaran NHT. Selain itu, meningkatnya pemahaman dan kinerja guru berdasarkan model pembelajaran Numbered Head Together (NHT) juga ikut mempengaruhi aktivitas belajar siswa.

Untuk mengetahui peningkatan hasil prestasi belajar siswa, peneliti menggunakan tes yang dibagikan pada siswa disetiap akhir siklus. Peningkatan hasil prestasi belajar siswa dapat dilihat pada Tabel berikut:

Tabel 5. Perkembangan Prestai Belajar IPS Siswa

\begin{tabular}{llll}
\hline No & Prestasi & Siklus I & Siklus II \\
\hline 1 & Tuntas & 18 & 21 \\
2 & Tidak tuntas & 4 & 1 \\
3 & Jumlah & 786 & 881 \\
4 & Rata-rata & 71,45 & 80,09 \\
5 & Persentase tuntas & 72,73 & 90,91 \\
\hline
\end{tabular}

Nilai tes evaluasi siklus I perolehan prosentase ketuntasan belajar klasikal IPS sebesar $72,73 \%$, dan siklus II meningkat menjadi 90,91\%, Hal ini menunjukkan bahwa dari siklus I ke siklus II, prestasi belajar siswa semakin 
meningkat dari tiap siklusnya dan guru juga sudah lebih menguasai model pembelajaran Numbered Head Together (NHT).

Berdasarkan catatan selama penelitian siklus 1, guru mengawali kegiatan dengan memotivasi siswa dan menjelaskan tujuan dari pembelajaran dan kegiatan yang harus dilakukan. Penelitian yang telah dilakukan mendapatkan beberapa hasil penelitian. 1).motivasi siswa yang masih kurang dimunculkan dalam kegiatan pembelajaran; 2).Prestasi belajar yang masih kurang juga terlihat pada subyek penelitian; 3) Rasa ingin tahu dan prestasi belajar siswa dapat meningkat karena pembelajaran yang dilakukan menggunakan model pembelajaran yang inovatif sehingga tampak keaktifan siswa dalam pembelajaran.

Dalam kegiatan tersebut Guru menggunakan model pembelajaran Numbered Head Together (NHT) dengan memanfaatkan media topi bernomor sebagai media untuk memfasilitasi siswa dalam kegiatan pembelajaran diskusi kelompok. Siswa diajak untuk menggali pengetahuan dengan diskusi kelompok model kepala bernomor dan guru menunjuk secara spontan salah satu siswa menjadi wakil dalam presentasi kelompoknya dapat menumbuhkan motivasi sehingga diikuti prestasi belajar yang meningkat.

Kegiatan berikutnya untuk mengukur prestasi diberikan LKS untuk dikerjakan siswa. Saat siswa mengerjakan LKS guru berkelililing untuk memberikan bimbingan. Setelah soal selesai dikerjakan dilanjutkan pembahasan sehingga diperoleh nilai. Penelitian yang dilakukan dengan menggunakan model pembelajaran Numbered Head Together (NHT) telah menjadikan siswa menggali informasi secara menyenangkan sehingga pemahaman siswa terhadap materi yang dipelajari menjadi berkesan dalam ingatan siswa. Motivasi siswa semakin muncul dalam setiap siklusnya. Siswa dalam mengerjakan angket menghasilkan skor yang semakin baik, sehingga peningkatan motivasi semakin terlihat. Prestasi belajar yang semakin meningkat terlihat pada hasil pekerjaan evaluasi siswa yang ketuntasan klasikalnya semakin meningkat pada setiap siklusnya.

Hal ini dapat kita lihat dari prosentase yang diperoleh dalam setiap siklusnya.Dari aktivitas yang dilakukan guru dan siswa dapat diperoleh hasil sebagi berikut : Aktivitas guru pada siklus I diperoleh nilai rata-rata sebesar 2,5 
dan siklus II sebesar 3,7. Ini menunjukkan bahwa kinerja guru mengalami peningkatan dari baik menjadi sangat baik baik. Perolehan nilai rata-rata pada siklus I sebesar 2,5 (61,4\%) yang berarti kinerja guru baik dan pada siklus II diperoleh nilai rata-rata sebesar 3,7 (92\%) yang berarti kinerja guru menjadi sangat baik. Dari data tersebut, menunjukkan bahwa kinerja guru dari siklus I ke siklus II mengalami peningkatan dari baik menjadi sangat baik.

Nilai tes evaluasi siklus I perolehan prosentase ketuntasan belajar klasikal IPS sebesar 72,73 \%, dan siklus II meningkat menjadi 90,91\%, Hal ini menunjukkan bahwa dari siklus I ke siklus II, prestasi belajar siswa semakin meningkat dari tiap siklusnya dan guru juga sudah lebih menguasai model pembelajaran Numbered Head Together (NHT). Hasil penelitian menjawab pertanyaan penelitian sehingga memenuhi semua kriteria keberhasilan dari penelitian. Berdasarkan deskripsi pelaksanaan tindakan siklus 1 dan siklus 2 yang telah menggunkan model pembelajaran Numbered Head Together (NHT).

Secara umum nilai rata - rata kelas mengalami peningkatan. Peningkatan nilai rata - rata tes sebelum tindakan mencapai 18 anak tidak tuntas tetapi menurun di siklus 1 menjadi 4 anak tidak tuntas dan menurun kembali di siklus 2 menjadi 1 anak yang tidak tuntas. Suatu proses pembelajaran dapat dikatakan baik apabila melibatkan proses berpikir. Dengan demikian siswa menggunakan kemampuan kognitif/intelektualnya. Dalam belajar IPS, siswa perlu menggunakan kemampuan kognitif tersebut untuk dapat menganalis masalah sosial budaya.

Abstraknya materi pembelajaran IPS seharusnya memotivasi guru untuk melakukan inovatif dalam pembelajaran sehingga tidak membosankan dan menumbuhkan aktivitas belajar siswa yang aktif dan diikuti meningkatnya prestasi. Peningkatan yang telah diperoleh dapat terus dimanfaatkan dan ditingkatkan kualitasnya dan diperlukan pengembangan lebih lanjut. Selain itu karena hasilnya positif secara nyata telah dapat diperoleh, pengembangan ini dapat disosialisasikan atau dideseminasikan kepada guru-guru dan sekolah yang lain. Oleh karena itu direncanakan beberapa tindak lanjut, Dan untuk meningkatkan prestasi siswa. 
Namun demikian penilitian ini juga memiliki keterbatasan, diantaranya : 1 ) beberapa siswa tidak serius mengikuti rangkaian tindakan ada sebagian murid yang asyik bermain - main sendiri sehingga membutuhkan pendampingan guru untuk dapat aktif dalam mengikuti pembelajaran.2). materi suku bangsa dan budaya sangat luas sehingga tidak semua terwakili dengan model pembelajaran Numbered Head Together (NHT).

\section{SIMPULAN}

Berdasarkan pembahasan yang telah dipaparkan sebelumya dapat ditarik kesimpulan sebagai berikut: 1) Model pembelajaran Kooperatif tipe Numbered Head Together dapat meningkatkan motivasi siswa kelas V SDN 2 Pandak, Korwilcam Dindik Baturraden pada mata pelajaran Ilmu Pengetahuan Sosial (IPS) materi Keanekaragaman Suku Bangsa dan Budaya di Indonesia. Hal tersebut ditunjukkan dengan rata-rata motivasi siswa meningkat dari siklus I ke siklus II yaitu dari jumlah 259 , persentase $42 \%$, rata-rata 25.6 dengan kriteria motivasi siswa cukup tinggi menjadi jumlah 536, presentase $87 \%$, rata-rata 38.29 dengan kriteria motivasi sangat tinggi. 2) Model pembelajaran Kooperatif tipe Numbered Head Together dapat meningkatkan prestasi belajar siswa kelas V SDN 2 Pandak, Korwilcam Dindik Baturraden pada mata pelajaran Ilmu Pengetahuan Sosial (IPS) materi Keanekaragaman Suku Bangsa dan Budaya di Indonesia. Hal tersebut ditunjukkan dengan Pada siklus I diperoleh persentase ketuntasan sebesar 72,73\% dengan nilai rata-rata sebesar 71,45, dan di siklus II meningkat menjadi 90,91\% dengan nilai rata-rata sebesar 80,09 .

\section{DAFTAR PUSTAKA}

Amin. 2009. Pendidikan Kewarganegaraan. Jakarta: Universitas Terbuka

Anitah, Sri, dkk. 2008. Strategi Pembelajaran di SD. Jakarta: Universitas Terbuka Aqib Zaenal. 2013. Model-model, Media, dan Strategi Pembelajaran Kontekstual (Inovatif). Bandung: Yrama Widya

Arifin,Z. 2009. Evaluasi Pembelajaran. Bandung: PT Remaja Rosdakarya Darmiatun. 2013. Implementasi Pendidikan Karakter di Sekolah. Yogyakarta. 
Gava

Rahayu 2006, Numbered Head Together Jakarta ,

PD Wijanarko, P Sukarjo 2014 , Joyful Learning Journal , Journal Unnes ac.id

Setiawati, Siti . 2013.Penggunaa Model Kooperatif Numbered Head Together (NHT).Jurnal Kalam Cendekia PGSD Solo : Universitas sebelas Maret Surakarta .

Sudjana, Nana .2011 . Penelitian Hasil Belajar Mengajar .Bandung :PT Remaja Rosdakarya. 